\section{Clear fluids three hours before surgery do not affect the gastric fluid contents of children}

William M. Splinter MD FRCP,

J. David Schaefer MD FRCS, Ian H. Zunder MD
This prospective, randomized, single-blind study of 121 healthy children aged 2 to 12 yr investigated the effect of clear fluids on gastric contents. Gastric fluid volume and $\mathrm{pH}$ were measured immediately following the induction of general anaesthesia and were not significantly affected by the ingestion of unlimited clear fluids up to three hours preoperatively. After a prolonged fast (mean fast $14 \mathrm{hr}$ ), gastric fluid volume was $0.39 \pm 0.37 \mathrm{ml} \cdot \mathrm{kg}^{-1}$ and gastric $\mathrm{pH}$ was $1.7 \pm 0.4$; after unlimited clear fluids $(203$ $\pm 109 \mathrm{ml}$ ) up to three hours before surgery gastric fluid volume was $0.34 \pm 0.28 \mathrm{ml} \cdot \mathrm{kg}^{-1}$ and gastric $\mathrm{pH}$ was $\mathrm{l} .8 \pm 0.7$ (mean $\pm S D)$. Gastric fluid volume $\left(\mathrm{ml} \cdot \mathrm{kg}^{-1}\right)$ increased in both the control and study groups as age increased, $P<0.005$. It is concluded that drinking clear fluid up to three hours before scheduled surgery does not have a measurable effect on gastric volume and $\mathrm{pH}$ of healthy children of ages 2 to $12 \mathrm{yr}$.

Cette étude prospective randomisée à simple insu chez 121 enfants en bonne santé agés de 2 à 12 ans a étudié les effets de l'administration de liquide clair sur le contenu gastrique. Le volume gastrique et son $\mathrm{pH}$ ont été mesurés immédiatement après l'induction de l'anesthésie générale et n'étaient pas significativement affectés par l'ingestion d'une quantité illimitée de liquide clair jusqu'à trois heures avant la chirurgie. Après un jeûne prolongé (jeûne moyen $=14$ heures), le volume du liquide gastrique était de $0,39 \pm 0,37 \mathrm{ml} \cdot \mathrm{kg}^{-1}$ et le $\mathrm{pH}$ gastrique était de $1,7 \pm 0.4$; après une quantité illimitée de liquide clair $(203 \pm 109 \mathrm{ml})$ jusqu'à trois heures avant la chirurgie, le volume du liquide gastrique était de $0,34 \pm 0,28$ $\mathrm{ml} \cdot \mathrm{kg}^{-1}$ et le $\mathrm{pH}$ gastrique était de $1,8 \pm 0,7$ (moyenne $\pm S D$ ).

\section{Key words}

ANAESTHESIA: paediatric;

COMPLICATIONS: aspiration, prophylaxis;

GASTROINTESTINAL TRACT: gastric emptying, gastric $\mathrm{pH}$, gastric volume, preoperative fluids.

From the Departments of Anaesthesia and Surgery, Children's Hospital of Eastem Ontario, University of Ottawa, Ottawa, Ontario, K1H 8Ll.

Address correspondence to: Dr. W. M. Splinter, Department of Anaesthesia, Children's Hospital of Eastem Ontario, 401 Smyth Rd., Ottawa, Ontario, K1H 8L1.
Le volume du liquide gastrique $\left(\mathrm{ml} \cdot \mathrm{kg}^{-1}\right)$ augmenta tant chez le groupe contrôle que le groupe étudié en fonction de l'âge, $P<$ 0,05 . On conclut que l'ingestion de liquide clair jusqu'à trois heures avant la chirurgie n' affecte pas d' une façcon mesurable le volume du liquide gastrique et son $\mathrm{pH}$ chez les enfants en bonne santé et âgés de 2 à 12 ans.

Patients are required to abstain from food and drink before surgery. In younger patients the resulting fast of 6 to 18 hours leads to thirsty, hungry and irritable children. ${ }^{1,2}$ In order to minimize these discomforts, the optimum length for this fast must be established.

Previous studies have demonstrated the safety and efficacy of administering specific volumes $(2-10 \mathrm{ml}$. $\mathrm{kg}^{-1}$ ) and types (water, apple juice, five per cent dextrose water and 20 per cent Poly-Joule) of clear fluids to children two to three hours before surgery. ${ }^{1-5}$ This study of healthy children compared the effect of an overnight fast with the effect of permitting unlimited clear fluids up to three hours before surgery on gastric fluid volume and $\mathrm{pH}$.

\section{Methods}

This study was approved by the Hospital Ethics Committee and parental consent was obtained. Patients were excluded from the study if there was a history of gastrointestinal disease or if the patient was receiving medication known to affect gastric contents.

One hundred and twenty-one healthy children aged 2-12 yr scheduled for elective surgery were randomly assigned to one of two groups. Children in Group A fasted from midnight. Children in Group B did not consume solid food on the day of their operation but were instructed to ingest unlimited volumes and types of clear fluids up to three hours before their scheduled surgery. For the purpose of this study clear fluids were defined as aqueous solutions, which are liquids at $37^{\circ} \mathrm{C}^{6,7}$ Non-clear fluids, suspensions and emulsions, such as milk and most broths, were not permitted. Parents or nursing staff were asked to monitor accurately the amount of fluid ingested on the day of surgery. 
TABLE I Patient characteristics mean \pm SD (range)

\begin{tabular}{|c|c|c|c|c|c|}
\hline Group & $n$ & $\begin{array}{l}\text { Age } \\
(y r)\end{array}$ & $\begin{array}{l}\text { Weight } \\
(\mathrm{kg})\end{array}$ & $\begin{array}{l}\text { Duration } \\
\text { of fast } \\
\text { (hr) }\end{array}$ & $\begin{array}{l}\text { Volume ingested } \\
(\mathrm{ml})\end{array}$ \\
\hline A & 64 & $5.7 \pm 2.5$ & $21 \pm 8$ & $13.9 \pm 2.5$ & nil \\
\hline B & 57 & $5.6 \pm 2.7$ & $23 \pm 12$ & $3.3 \pm 0.9$ & $203 \pm 109(30-630)$ \\
\hline
\end{tabular}

The following protocol was used in all patients:

a Anaesthesia was induced IV with thiopentone or by inhalation of halothane and nitrous oxide/oxygen. A tracheal tube was inserted when indicated.

b After the establishment of an adequate and stable level of anaesthesia, a 16 Fr. Salem ${ }^{\boxplus}$ oro-gastric tube was passed by the same investigator, who was unaware of the patient's fasting status. The position of the tube was confirmed by auscultation. Stomach contents were consistently aspirated with the gastric tube in several positions and with the patient supine, tilted to the right, left, head down and head up positions. Gastric contents were visually inspected for particles; the volume was measured by syringe; and $\mathrm{pH}$ was evaluated with $\mathrm{pH}$ paper (Merck pH 0-14 and pH 0-2.5). An acceptable correlation between the results determined by Merck paper and various $\mathrm{pH}$ electrodes has been noted. ${ }^{8}$ Gastric volumes less than $1 \mathrm{ml}$ were assigned the value of $0.5 \mathrm{ml}$.

For the purpose of this study "risk" factors for aspiration pneumonia were defined as (1) intragastric $\mathrm{pH}$ $\geq 2.5$ and fluid volume $\leq 0.4 \mathrm{ml} \cdot \mathrm{kg}^{-1}$ and (2) intragastric fluid voluid volume $\geq 1.0 \mathrm{ml} \cdot \mathrm{kg}^{-1}$.

Comparisons between groups were made using an unpaired Student's t test for parametric data (e.g., weight, age) and Mann-Whitney- $U$ tests for non-parametric data (e.g., sex, gastric $\mathrm{pH}$ and gastric volume). The differences between the groups' risk factors for pulmonary acid-aspiration syndrome were assessed by Fisher's exact test or Chi-square analysis. The potential relationship between gastric fluid volume and $\mathrm{pH}$ versus gender, age, weight, in-patient/out-patient status, volume ingested and length of fast was evaluated by linear regression analysis. Differences were considered statistically significant if $P$ $<0.05$. Sample size was determined by assuming the standardized difference would be 0.6 and by setting the power at 0.90 .

TABLE II Gastric contents mean \pm SD (range)

\begin{tabular}{lll}
\hline Group & Volume $\left(\mathrm{ml} \cdot \mathrm{kg}^{-1}\right)$ & $p H$ \\
\hline A & $0.39 \pm 0.37(0.04-1.97)$ & $1.7 \pm 0.4(1.1-4.0)$ \\
B & $0.34 \pm 0.28(0.03-1.53)$ & $1.8 \pm 0.7(1.2-5.0)$ \\
\hline
\end{tabular}

\section{Results}

There were no sigificant differences between the groups' gender, age, weight or ASA physical status (Table I). The timing and volume of fluid ingested varied among the patients in Group B. Children in Group B drank $203 \pm$ $109 \mathrm{ml}\left(10.4 \pm 6.7 \mathrm{ml} \cdot \mathrm{kg}^{-1}\right)$ of clear fluids up to $3.3 \pm$ $0.9 \mathrm{hr}$ before induction of anaesthesia. (Values are listed as mean $\pm \mathrm{SD}$.) Fluids ingested on the day of surgery included clear fruit juices, water, soda pop, Popsicles ${ }^{\circledR}$ Kool Aid ${ }^{\circledR}$ and Jello ${ }^{\oplus}$. Various fasting times occurred because of changes in operating room schedules or because the child did not wish a drink three hours before surgery as they had recently ingested fluids and thus were not thirsty. The volume of fluids ingested on the day of surgery varied considerably. This was primarily due to the different appetites of children. Also, bias may have been induced by previous warnings to parent and child about the "risks" of drinking on the day of surgery so that the volumes ingested may have been reduced.

Neither gastric fluid volume nor $\mathrm{pH}$ were affected by the ingestion of clear fluids (Table II). Patients drinking clear fluids had a decreased incidence of gastric fluid volume $>1.0 \mathrm{ml} \cdot \mathrm{kg}^{-1}$ (Table III). Two patients in each group had particulate matter in their gastric juice.

Linear regression analysis indicated that neither gastric fluid volume nor $\mathrm{pH}$ varied with gender, in-patient/ out-patient status, volume ingested and length of fast, but as age increased gastric volume $\left(\mathrm{ml} \cdot \mathrm{kg}^{-1}\right)$ increased, $P<$ $0.005, \mathrm{R}^{2}=12$ per cent.

\section{Discussion}

In this study, the gastric fluid volume and $\mathrm{pH}$ of healthy children determined immediately after induction of anaes-

TABLE III Per cent of patients with "risk" factors for pulmonary acid-aspiration syndrome

\begin{tabular}{lll}
\hline & $\begin{array}{l}\text { Gastric volume }> \\
0.4 \mathrm{ml} \cdot \mathrm{kg}^{-1}\end{array}$ & $\begin{array}{l}\text { Gastric volume }> \\
\text { and } \mathrm{pH}<2.5 \mathrm{ml} \cdot \mathrm{kg}^{-1}\end{array}$ \\
\hline A & 33 & $11^{*}$ \\
B & 32 & 2 \\
\hline
\end{tabular}

$* P<0.05$, Fisher exact test. 
thesia was not altered by permitting the ingestion of clear fluids up to three hours before elective surgery. Based on previous investigations of gastric emptying of clear fluids in adults, ${ }^{9-11}$ and the results of studies of the ingestion of a preset volume at a specific time by children ${ }^{1-5}$ our results were expected.

Clear fluids rapidly empty from the stomach of healthy patients. This emptying follows first-order kinetics, being primarily a function of the pressure gradient between the stomach and the duodenum. ${ }^{9,10}$ It is also altered by the composition of the fluid consumed. ${ }^{9}$ Isotonic solutions which do not interact with duodenal osmotic receptors (e.g., normal saline and $33 \mathrm{mM}$ trisodium citrate) have gastric half-lives of only three to five minutes. ${ }^{10}$ Aqueous solutions containing glucose, protein and lipids have gastric half-lives of about ten minutes. ${ }^{9}$ With a half-life of ten minutes the percentage of clear fluid consumed which was present after a three-hour fast would be 0.0004 per cent, assuming a continuation of first-order kinetics. To augment further gastric emptying of clear fluids, it has been demonstrated in healthy adults that the terminal phases of gastric emptying of clear fluids is faster than expected. ${ }^{11}$ Alternatively, one can consider the expected volume of retained fluids if the gastric emptying rate is at the lower limit of "normal" instead of the average normal value. Recovery of $>200 \mathrm{ml}$ of gastric fluid 30 min after a $750 \mathrm{ml}$ saline load test is considered abnormal gastric retention. ${ }^{9}$ After a three-hour fast, the percentage of retained fluid (saline) at the lowest limit of normal gastric emptying would be 0.04 per cent.

Solid food has markedly different gastric emptying. It is normal to find a portion (about $10-30$ per cent) of a solid-food meal still in the stomach six to eight hours after a large meal. ${ }^{12}$ This investigation described the effect of clear fluid ingestion on the day of surgery on gastric contents of healthy children. The results of this study cannot be applied to the gastric emptying of solid food.

Gastric emptying may be adversely affected by disease and medication. ${ }^{9}$ Drugs that inhibit gastric emptying include opiates, anticholinergics, beta-adrenergic agonists, L-dopa and tricylic antidepressants. ${ }^{8}$ The results of this study should not be extrapolated to children receiving these medications.

The model used in this study to classify patients at increased "risk" of pulmonary acid-aspiration syndrome was based upon the standard criteria of gastric volume $>0.4 \mathrm{ml} \cdot \mathrm{kg}^{-1}$ and gastric $\mathrm{pH}$ levels $>2.5 .^{13}$ This "standard" predicts that a large number (about 40 per cent) of children are at risk of pulmonary acid-aspiration syndrome. However, the actual incidence of aspiration pneumonitis is only $1-6$ per 10,000 adult surgical cases. ${ }^{14}$ (The incidence of perioperative aspiration pneumonia among healthy children undergoing elective sur- gery has not been reported.) This standard overestimates risk. Markedly elevated gastric fluid volume, increased intra-abdominal pressure and gastroesophageal reflux are factors of greater clinical relevance. ${ }^{13,14}$

An unexpected finding was the significant increase in gastric fluid volume as age increased. This may represent a normal physiological occurrence, or a chance event or our technique of gastric fluid volume estimation may underestimate small gastric volumes to a greater extent than it underestimates larger volumes. Further study is indicated.

The technique used to measure the volume of gastric contents is a valid and accepted method, ${ }^{15}$ although it underestimates gastric volume. Dye-dilution techniques are cumbersome and of unknown precision in children.

In summary, gastric fluid contents immediately after the induction of anaesthesia of healthy 2- to 12-yr-old children were not adversely affected by the ingestion of unlimited types and volumes of clear fluids up to three hours before their operation. Thus, the policy of restricting clear fluid intake more than three hours before surgery does not benefit children and may lead to thirst, hunger and poor behaviour. The effect on gastric contents of the ingestion of unlimited clear fluids less than three hours before anaesthesia, or if they are ingested by patients who are younger or older than those studied herein is unknown.

\section{Acknowledgements}

The authors would like to thank their anaesthesia colleagues, surgeons, and nurses for their cooperation; Drs. Elliot Rhine and Howard Nathan for advice; and Dr. Barry Garner for assistance with statistical analysis.

\section{References}

1 Splinter WM, Stewart JA, Muir JG. The effect of preoperative apple juice on gastric contents, thirst, and hunger in children. Can J Anaesth 1989; 36: 55-8.

2 Splinter WM, Stewart JA, Muir JG. Large volumes of apple juice preoperatively do not affect gastric $\mathrm{pH}$ and volume in children. Can J Anacsth 1990; 37: 36-9.

3 van der Walt $J H$, Carter $J A$. The effect of different pre-operative feeding regimens on plasma glucose and gastric volume and $\mathrm{pH}$ in infancy. Anaesth Intensive Care 1986; 14: 352-9.

4 Farrow-Gillespie A, Christensen S, Lerman J. Effect of the fasting interval on gastric $\mathrm{pH}$ and volume in children. Anesth Analg 1988; 67: S59.

5 Sandhar BK, Maltby JR, Goresky G, Strunin L. Preoperative fluids and ranitidine in children. Br J Anaesth 1987; 59: 324P-5P.

6 Manual of Clinical Dietetics. Chicago: American Dictetic Association, 1988, 171-3. 
7 Murray DP, Welsh JD, Rankin RA, Warner R. Survey: Use of clear fluid and full liquid diets with or without commercially produced formulas. J Parenter Enteral Nutr 1985; 9: 732-4.

8 Brock-Utne JG, Rout C, Moodley J, Mayat N. Influence of preoperative gastric aspiration on the volume and $\mathrm{pH}$ of gastric contents in obstetric patients undergoing Caesarian section. Br J Anaesth 1989; 62: 397-401.

9 Minami H, McCallum RW. The physiology and pathophysiology of gastric emptying in humans. Gastroenterology 1984; 86: 1592-610.

10 Erskine L, Hunt $J N$. The gastric emptying of small volumes given in quick succession. J Physiol 1981; 313 : 335-41.

11 Hunt JN, MacDonald I. The influence of volume on gastric cmptying. J Physiol 1954; 126: 459-74.

12 Moore JG, Christian PE, Coleman RE. Gastric emptying of varying meal weight and composition in man.

Evaluation by dual liquid- and solid-phase isotopic method. Dig Dis Sci 1981; 26: 16-22.

13 Plourde G, Hardy JF. Aspiration pneumonia: assessing the risk of regurgitation in the cat. Can Anaesth Soc J 1986; 33: 345-8.

14 Hardy J-F. Large volume gastroesophageal reflux: a rationale for risk reduction in the perioperative period. Can J Anaesth 1988; 35: 162-73.

15 Hardy J-F, Plourde G, Lebrun M, Cote C, Dube S, Lepage $Y$. Determining gastric contents during general anaesthesia: evaluation of two methods. Can J Anaesth 1987; 34 : 474-7. 